\title{
SEROLIS AGASSIZI, NEW SPECIES, FROM THE DEEP SEA OFF CAPE FEAR, NORTH CAROLINA (CRUSTACEA: ISOPODA)
}

\author{
Robert Y. George
}

\begin{abstract}
A new species of isopod Serolis agassizi is described. This blind deep-sea species was collected at 3840 meters over the continental rise off the coast of North Carolina. The abyssal species is the fourth member of the polytypic genus Serolis occurring north of the equator and its affinity with two shallow Northern Hemisphere species, $S$. carinata from the California coast, and $S$. mgrayi from the Georgia coast, is discussed. Its resemblance to the other abyssal blind species $S$. vemae is pointed out.
\end{abstract}

The isopod species belonging to the family Serolidae are morphologicaly distinctive due to their flattened body form. Out of the approximately 50 known species of the genus Serolis, only three have been found so far to occur north of the equator; all other species live in the Southern Hemisphere where they are particularly diverse and abundant in the cold waters of the Antarctic shelf and subantarctic islands (Nordenstam 1933; Sheppard 1933). Lockington (1877) discovered Serolis carinata, the first record of this genus in the Northern Hemisphere, in shallow waters off the coast of southern California. A second serolid species, $S$. mgrayi, was described by Menzies and Frankenberg (1966) from the continental shelf off Georgia. Hessler (1972) pointed out that these two shallow-water serolid species from the Northern Hemisphere, one from the Atlantic and the other from the Pacific coast, are closely related sibling species isolated geographically by the Central American land bridge. The speciation of these two species took place as a consequence of their geographic separation.

The third known Northern Hemisphere serolid species, $S$. vemae, was first reported from a depth of 5024 meters over the Argentine Rise southeast of Rio Grande in the South Atlantic Ocean (Menzies 1962). Se- rolis vemae was later captured in good numbers from a depth of 2862-4749 meters in the North Atlantic Ocean (Hessler 1967). The present paper describes the second abyssal species of Serolis from a depth of 3840 meters over the continental rise off North Carolina in the Northwest Atlantic Ocean. This new serolid species, S. agassizi, was collected during a cruise of R/V Eastward and is named in honor of Alexander Agassiz who made significant contributions to our understanding of the deep-sea fauna of the North Atlantic Ocean.

\section{Serolis Leach, 1818}

Diagnosis. - Serolidae markedly flattened, not known to conglobate; coxal plates laterally expanded. Mandible with lacinia mobilis. Maxilliped with 3-articled palp. Pereopod 2 sexually dimorphic, in female ambulatory and in male subchelate. Pleopods 1-3 each with elongate peduncle and subelliptical rami. Uropoda biramous.

Serolis agassizi, new species

Figs. 1, 2

Diagnosis. - Serolis with coxal plates visible dorsally in pereonal somites 2 to 4 . Body configuration somewhat globular. Cephalon lacking eyes. Lateral margin of all pereonal 


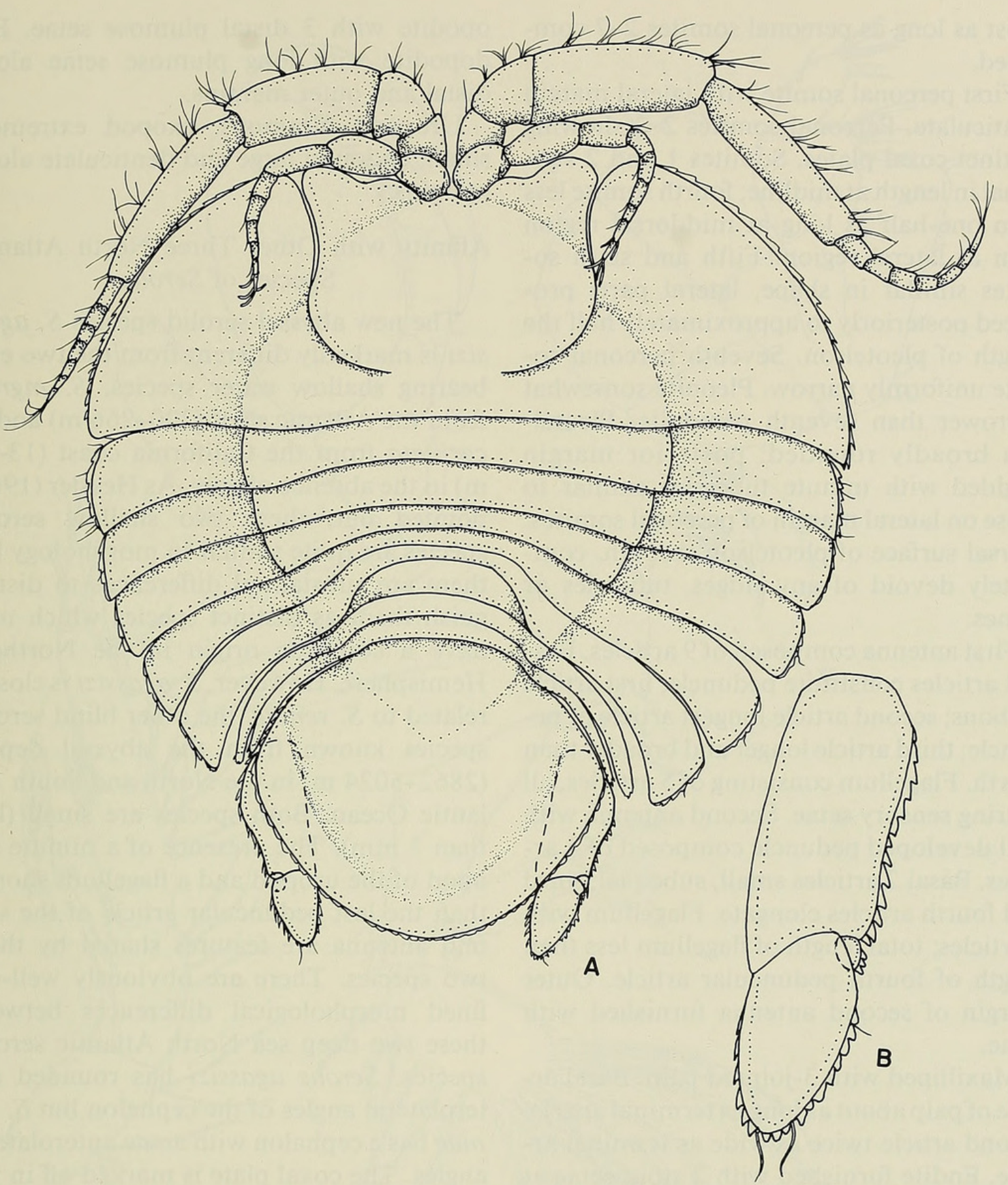

Fig. 1. Serolis agassizi, holotype female, length $3.0 \mathrm{~mm}$ : A, Dorsal view; B, Uropod.

somites denticulate. Pereonal somite 1 fused with cephalon. Pleotelson globular; posterior margin broadly rounded, denticulate. Lateral margin of uropod biramous; exopod minute; endopod enlarged, with lateral margin denticulate.

Material examined.-Holotype female, length $3 \mathrm{~mm}$, width $2.5 \mathrm{~mm}$ (USNM 138717).

Type-locality._Continental rise off North
Carolina coast. R/V Eastward Sta 6214,1 female, $3840-3975 \mathrm{~m}, 33^{\circ} 01.5^{\prime}-33^{\circ} 03.0^{\prime} \mathrm{N}$, $75^{\circ} 06.2^{\prime}-75^{\circ} 6.5^{\prime} \mathrm{W}, 5$ Nov 1966 ; collected with Small Biological Trawl.

Description.-Body shape globular with lateral margin denticulate and furnished with minute setae. Cephalon with large rostrum separated from lateral lobes by narrow furrow on either side of rostrum. Eyes entirely absent, ocular ridge lacking. Cephalon al- 
most as long as pereonal somites $2-7$ combined.

First pereonal somite with lateral margin denticulate. Pereonal somites 2-3 showing distinct coxal plates. Somites 1 and 2 subequal in length at midline; fourth somite less than one-half as long at middorsal region than at lateral region. Fifth and sixth somites similar in shape, lateral parts produced posteriorly to approximately half the length of pleotelson. Seventh pereonal somite uniformly narrow. Pleonite somewhat narrower than seventh pereonite. Pleotelson broadly rounded; posterior margin studded with minute tubercles similar to those on lateral margin of pereonal somites. Dorsal surface of pleotelson smooth, completely devoid of any ridges, tubercles or spines.

First antenna composed of 9 articles. Basal 4 articles constitute peduncle; first article bulbous; second article longest article of peduncle; third article longer and broader than fourth. Flagellum consisting of 5 articles, all bearing sensory setae. Second antenna with well developed peduncle composed of 4 articles. Basal 2 articles small, subequal; third and fourth articles elongate. Flagellum with 7 articles; total length of flagellum less than length of fourth peduncular article. Outer margin of second antenna furnished with setae.

Maxilliped with 3-jointed palp. Basal article of palp about as long as terminal article; second article twice as wide as terminal article. Endite furnished with 2 stout setae at distal end. Epipodite marked off from basopodite by distinct suture.

First pereopod with elongate basis longer than carpus, ischium and merus combined. Propodus enlarged, displaying row of spines along inner margin. Dactylus about as long as propodus; both combined into claw-like configuration. Seventh pereopod with subequal joints and reduced dactylus; merus bearing 3 leaf-like setae at outer distal edge.

Third pleopod with triangular basopodite; endopodite larger than exopodite. Ex- opodite with 3 distal plumose setae. Endopodite with long plumose setae along distal and outer margins.

Uropoda biramous, exopod extremely small; endopod large and denticulate along margins.

Affinity with Other Three North Atlantic Species of Serolis

The new abyssal serolid species $S$. agassizi is markedly different from the two eyebearing shallow water species, $S$. mgrayi from the Atlantic shelf (200-266 m) and $S$. carinata from the California coast (13-56 $\mathrm{m}$ ) in the absence of eyes. As Hessler (1967) pointed out, these two shallow serolid species are quite similar in morphology but there are substantial differences to distinguish them as distinct species which may have a common origin in the Northern Hemisphere. However, $S$. agassizi is closely related to $S$. vemae, the other blind serolid species known from the abyssal depths $(2862-5024 \mathrm{~m})$ in the North and South Atlantic Ocean. Both species are small (less than $5 \mathrm{~mm}$ ). The presence of a minute exopod of the uropod and a flagellum shorter than the last peduncular article of the second antenna are features shared by these two species. There are obviously well-defined morphological differences between these two deep sea North Atlantic serolid species. Serolis agassizi has rounded anterolateral angles of the cephalon but $S$. vemae has a cephalon with acute anterolateral angles. The coxal plate is marked off in pereonal somite 5 in $S$. vemae but not in this new species. Serolis agassizi has a smooth dorsal surface but denticulate lateral margin. Serolis vemae has a small tubercle on pereonal somites 5 and 6 and a smooth lateral margin. The pleotelson shape is very different between these two species, the apex broadly rounded in $S$. agassizi and somewhat tapering in $S$. vemae. The second article of the maxilliped palp is elongate and the terminal third article small in $S$. vemae. The second article of the maxilliped palp is 


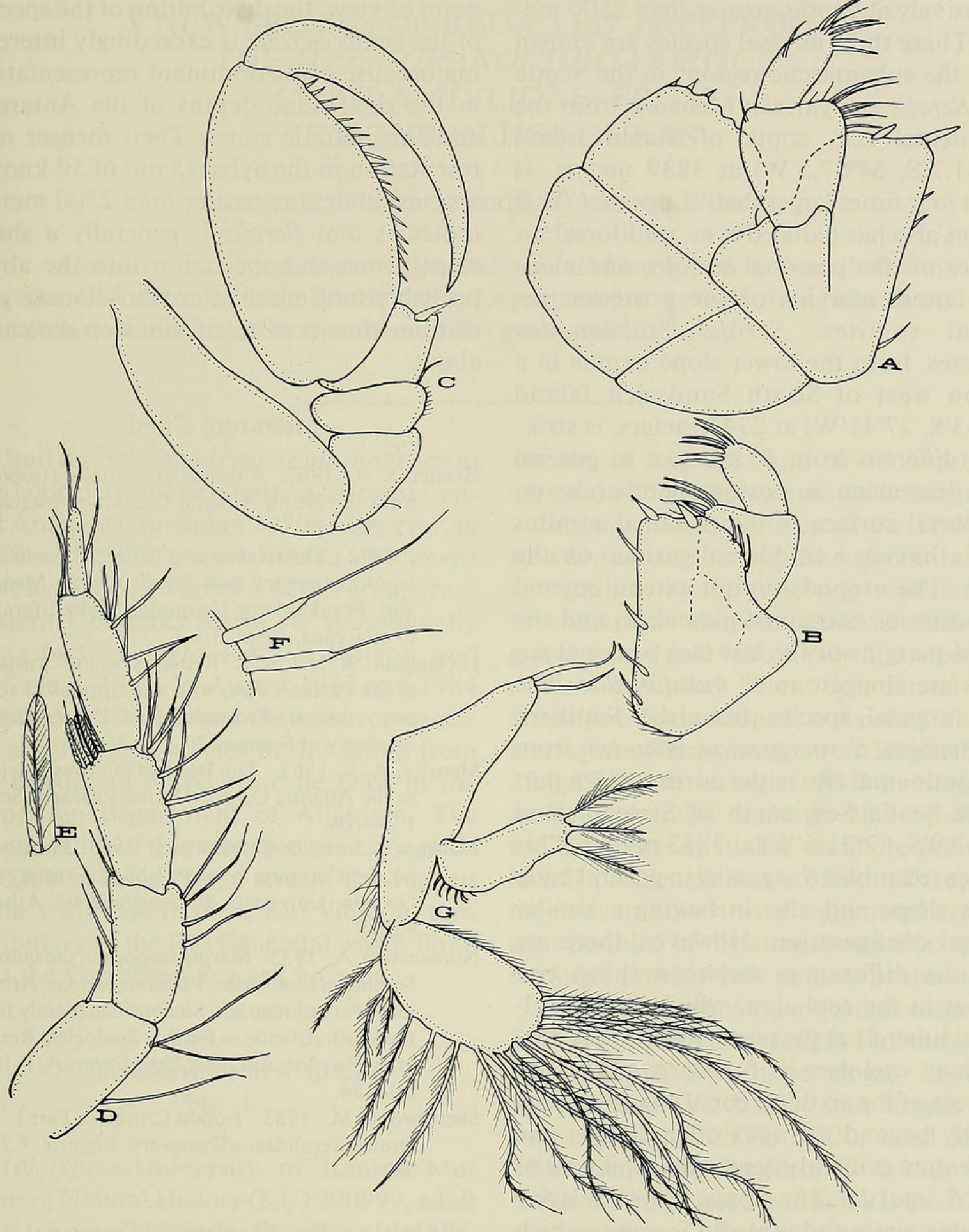

Fig. 2. Serolis agassizi, holotype female, length $3.0 \mathrm{~mm}$ : A, Maxilliped; B, Maxilliped, ventral view; C, first pereopod; D, Second pereopod; E-F, setae enlarged; G, Second pleopod.

only slightly longer than the terminal third article in $S$. agassizi. These points of difference clearly differentiate the two abyssal species of Serolis in the Northern Hemisphere.
Affinity with Abyssal Species of Serolis from the South Atlantic Ocean

Besides these two species, there are only three other species of Serolis known to live 
exclusively at depths greater than 2500 meters. These three abyssal species are known from the subantarctic regions in the Scotia Sea. Serolis maryannae Menzies, from the continental rise, south of Staten Island $\left(55^{\circ} 31.2^{\prime} \mathrm{S}, 64^{\circ} 07.5^{\prime} \mathrm{W}\right)$ at 3839 meters, is about four times larger than $S$. agassizi. This species also has reduced eyes, middorsal tubercles on the pereonal somites and elongate lateral margins of the posterior pereonal somites. Serolis macdonellae Menzies, from the lower slope depths in a region west of South Sandwich Island $\left(56^{\circ} 43^{\prime} \mathrm{S}, 27^{\circ} 41^{\prime} \mathrm{W}\right)$ at 2741 meters, is strikingly different from $S$. agassizi in general body dimension, in possessing tubercles on the dorsal surface of the pereonal somites and in having a middorsal carinae on the pleon. The uropods do not extend beyond the posterior margin of pleotelson and the lateral margins of the last two pereonal somites are elongate in $S$. macdonellae. The third abyssal species from the Southern Hemisphere, $S$. margaretae, is known from the continental rise in the northwestern part of the Scotia Sea, south of Staten Island $\left(55^{\circ} 42.9^{\prime} \mathrm{S}, 62^{\circ} 21.6^{\prime} \mathrm{W}\right)$ at 3813 meters. This species resembles $S$. agassizi in general body shape shape and also in having a similar pleonal configuration. However, there are obvious differences between these two species in the cephalon, which has a middorsal tubercle at the posterior end and conspicuous eyelobes in $S$. margaretae. The epimera of the sixth pereonal somite extend slightly beyond the apex of the telson and this feature evidently demarcates this species from $S$. agassizi. The closest known relative of $S$. agassizi is undoubtedly $S$. vemae which inhabits the abyssal depths of both northern and southern hemispheres in the Atlantic Ocean.

From a zoogeographic and evolutionary point of view, the distribution of the species of the genus Serolis is exceedingly interesting because of its dominant representation in the shelf-slope depths of the Antarctic and subantarctic zones. Their meager representation in the aybss ( 5 out of 50 known species) in depths greater than 2500 meters indicates that Serolis is generally a shelfslope genus and speciation into the abyss probably took place after the Miocene glaciation when cooling of the deep sea came about.

\section{Literature Cited}

Hessler, R. R. 1967. A record of Serolidae (Isopoda) from the North Atlantic Ocean.-Crustaceana 12:159-162.

1972. The relationship between Serolis carinata Lockington and Serolis mgrayi Menzies and Frankenberg (Isopoda, Flabellifera).Crustaceana, suppl. 3:1-6.

Lockington, W. N. 1877. Remarks on the Crustacea of the Pacific Coast, with descriptions of some new species.-Proceedings of the California Academy of Sciences 7(1):28-36.

Menzies, R. J. 1962. The Isopods of abyssal depths in the Atlantic Ocean.-Vema Research Series $1: 79-106$.

Menzies, R. J. and D. Frankenberg. 1966. Handbook on the Common Marine Isopod Crustacea of Georgia. University of Georgia Press, Athens, $93 \mathrm{pp}$.

Nordenstam, A. 1933. Marine Isopoda of the families Serolidae, Idotheidae, Pseudidotheidae, Arcturidae, Parasellidae and Stenetriidae mainly from the South Atlantic. - Further Zoological Results of the Swedish Antarctic Expedition 1901-1903 3:1-184.

Sheppard, E. M. 1933. Isopod Crustacea Part I. The family Serolidae.-Discovery Reports 7:253362.

Institute for Marine Biomedical Research, University of North Carolina at Wilmington, Wilmington, North Carolina 28403. 


\section{$2 \mathrm{BHL}$ Biodiversity Heritage Library}

George, Robert Y. 1986. "Serolis agassizi, New Species, From The Deep sea Off Cape Fear, North carolina (Crustacea, Isopoda)." Proceedings of the Biological Society of Washington 99, 46-50.

View This Item Online: https://www.biodiversitylibrary.org/item/107581

Permalink: https://www.biodiversitylibrary.org/partpdf/45418

\section{Holding Institution}

Smithsonian Libraries

\section{Sponsored by}

Biodiversity Heritage Library

\section{Copyright \& Reuse}

Copyright Status: In copyright. Digitized with the permission of the rights holder.

Rights Holder: Biological Society of Washington

License: http://creativecommons.org/licenses/by-nc-sa/3.0/

Rights: https://biodiversitylibrary.org/permissions

This document was created from content at the Biodiversity Heritage Library, the world's largest open access digital library for biodiversity literature and archives. Visit BHL at https://www.biodiversitylibrary.org. 